UDC 621.74:669.2/8:669.017:669.182.71

DOI: 10.30838/J.PMHTM.2413.230419.54.294

\title{
EFFECTIVE METHOD OF TIN-FREE FOUNDRY BRONZE REFINING FROM ENDOGENOUS ORIGIN IMPURITIES
}

\author{
UZLOV K.I. ${ }^{1 *}$, Dr. Sc. (Tech.), Prof., \\ MOVCHAN A.V. ${ }^{2}, P h . D$., Senior Sc., \\ DZIUBINA A.V. ${ }^{3}$, Postgraduate Student, \\ BELAYA E.V. ${ }^{4}$, Master
}

\begin{abstract}
${ }^{1 *}$ Material Science Department named after Yu.N. Taran-Zhovnir, National Metallurgical Academy of Ukraine, 4, Gagarina ave., 49600, Dnipro, Ukraine, tel. +38(097)950-14-08, e-mail: konst.uzlov@gmail.com, ORCID ID: 0000-0003-0744-9890

${ }^{2}$ Heat Treatment of Metals Department named after K.F. Starodubov, National Metallurgical Academy of Ukraine, 4, Gagarina ave., 49600, Dnipro, Ukraine, tel. +38(097)128-17-81, e-mail: alvl.movchan@gmail.com

${ }^{3}$ Material Science Department named after Yu.N. Taran-Zhovnir, National Metallurgical Academy of Ukraine, 4, Gagarina ave., 49600, Dnipro, Ukraine, tel. +38(093)205-29-37, e-mail: alinadzubina@gmail.com

${ }^{4}$ Material Science Department named after Yu.N. Taran-Zhovnir, National Metallurgical Academy of Ukraine, 4, Gagarina ave., 49600, Dnipro, Ukraine, tel. +38(097)215-23-93, e-mail: geben.seele@gmail.com
\end{abstract}

Abstract. Problem statement. Ukraine in the ranking of leading suppliers of castings from copper alloys is among the top ten. In recent years there has been a rapid rise in their production. This is due to expansion of demand for copper alloys not only in electrical engineering, but also in other areas of industry, in particular in automotive manufacturing of electric cars production. Purpose. Copper-aluminum-iron system alloys structure formation regularities analysis depending on amount of alloying components changing for technological recommendations development of a stable high level of mechanical properties of foundry bronzes obtaining in industrial production and operation. Material and Methods. Material of the study was casting bronze BrA9Zh3L according to GOST 493 requirements. Microstructure was investigated on metallographic specimens prepared according to standard methods as per ASTM E3-11. Analysis was performed using light microscopy on "Neophot-2" equipment. Scanning electron microscopy and X-ray spectral microanalysis were performed on Superprobe-733 equipment. Results. With the help of $\mathrm{Cu}, \mathrm{Al}, \mathrm{Fe}$ components binary and triple systems equilibrium diagrams studies results comparative analysis, X-ray spectral microscopy and local X-ray energy dispersion methods the controversial issue concerning iron-containing phase in BrA9Zh3L bronze structure origin has been solved. It has been found that this is $\beta_{1}$ phase, i.e. $\mathrm{Fe}_{3} \mathrm{Al}$ with dissolved copper atoms (up to 7,72 wt. \%) and zinc in amount from 0,0 wt. $\%$ to 0,68 wt. $\%$, depending on this component content in alloy. Centrifugal casting method effective technological parameters industrial testing have been discovered that its disadvantages associated with bundle of casting material liquation can be used in production as advantage for melt included endogenous origin impurities refining, in particular, iron-containing $\mathrm{Fe}_{3} \mathrm{Al}$ phase. Conclusions. Controversial issue concerning iron-containing phase in bronze BrA9Zh3L structure genesis has been solved. It has been established that this is a phase of endogenous origin $\beta_{1}$, that is, $\mathrm{Fe}_{3} \mathrm{Al}$. Centrifugal casting method effective technological parameters for the melt included endogenous origin impurities refining have been used in production.

Keywords: copper alloys; centrifugal casting; casting bronze; structural formation; phase composition; doping; X-ray spectral microscopy analysis

\section{ЕФЕКТИВНИЙ СПОСІБ РАФІНУВАННЯ БЕЗОЛОВ'ЯНОГО БРОНЗОВОГО ЛИТВА ВІД ДОМІШОК ЕНДОГЕННОГО ПОХОДЖЕННЯ}

\author{
УЗЛОВ К. І. ${ }^{*}$, д. m. н., проф., \\ МОВЧАН О. В. ${ }^{2}$, к. т. н., провідн. фахівець, \\ ДЗЮБІНА А. В. ${ }^{3}$, аспірант, \\ БІЛА С. В. ${ }^{4}$, магістр
}

\footnotetext{
${ }^{1 *}$ Кафедра матеріалознавства ім. Ю. М. Тарана-Жовніра, Національна металургійна академія України, пр. Гагаріна, 4, 49600, Дніпро, Україна, тел. +38(097)950-14-08, e-mail: konst.uzlov@gmail.com, ORCID ID: 0000-0003-0744-9890

${ }^{2}$ Кафедра термічної обробки металів ім. К. Ф. Стародубова, Національна металургійна академія України, пр. Гагаріна, 4, 49600, Дніпро, Україна, тел. +38(097)128-17-81, e-mail: alvl.movchan@gmail.com

${ }^{3}$ Кафедра матеріалознавства ім. Ю. М. Тарана-Жовніра, Національна металургійна академія України, пр. Гагаріна, 4, 49600, Дніпро, Україна, тел. +38(093)205-29-37, e-mail: alinadzubina@gmail.com

${ }^{4}$ Кафедра матеріалознавства ім. Ю. М. Тарана-Жовніра, Національна металургійна академія України, пр. Гагаріна, 4, 49600, Дніпро, Україна, тел. +38(097)215-23-93, e-mail: geben.seele@gmail.com
} 
Анотація. Постановка проблеми. Україна в рейтингу провідних постачальників виливків 3 мідних сплавів входить в першу десятку. В останні роки спостерігається стрімкий підйом їх виробництва. Це пояснюється розширенням попиту на мідні сплави не тільки у електротехнічній, але й у інших областях промисловості, зокрема в автомобільній галузі при виробництві електрокарів. Мета роботи. Аналіз закономірностей формування структури сплавів системи мідь - алюміній - залізо при зміні кількості легуючих компонентів для розробки технологічних рекомендацій щодо одержання стабільно високого рівня механічних властивостей ливарних бронз у промисловому виробництві та в експлуатації. Матеріaл ma методика. Матеріалом дослідження була ливарна бронза БрА9Ж3Л за вимогами ГОСТ 493. Мікроструктуру досліджували на металографічних шліфах виготовлених за стандартними методиками по ASTM E3-11. Аналіз здійснювали за допомогою світлової мікроскопії на устаткуванні «Neophot-2». Растрові електронномікроскопічні дослідження та рентгеноспектральний мікроаналіз проводили на обладнанні Superprobe-733. Результати. За допомогою зіставного аналізу результатів досліджень діаграм фазових рівноваг бінарних та потрійних систем компонентів $\mathrm{Cu}, \mathrm{Al}, \mathrm{Fe}$, методів рентгеноспектрального мікроскопічного та локального рентгенівського енергодисперсійного вирішене суперечливе питання щодо походження залізовмісної фази у структурі бронзи БрА9Ж3Л. Встановлено, що це фаза $\beta_{1}$, тобто $\mathrm{Fe}_{3} \mathrm{Al}$ з розчиненими атомами міді (до 7,72 мас. \%) та цинку від 0,0 мас. \% до 0,68 мас. \%, в залежності від вмісту цього компоненту в сплаві. Промисловими випробуваннями ефективних технологічних параметрів методу відцентрового лиття встановлено, що його недоліки, пов'язані з розшаруванням матеріалу виливка за лікватами, можуть бути використаними у виробництві як перевага для рафінування розплаву при наявності в ньому домішок ендогенного походження, зокрема залізовмісної фази $\mathrm{Fe}{ }_{3} \mathrm{Al}$. Висновки. Вирішене суперечливе питання щодо генезису залізовмісної фази у структурі бронзи БрА9Ж3Л. Встановлено, що це фаза ендогенного походження $\beta_{1}$, тобто $\mathrm{Fe}_{3} \mathrm{Al}$. У виробництві використані ефективні технологічні параметри методу відцентрового лиття для рафінування розплаву при наявності в ньому домішок ендогенного походження.

Ключові слова: мідні сплави; відцентрове лиття; ливарна бронза; структуроутворення; фазовий склад; легування; рентгеноспектральний мікроскопічний аналіз

\title{
ЭФФЕКТИВНЫЙ СПОСОБ РАФИНИРОВАНИЯ БЕЗОЛОВЯННОГО БРОНЗОВОГО ЛИТЬЯ ОТ ПРИМЕСЕЙ ЭНДОГЕННОГО ПРОИСХОЖДЕНИЯ
}

\author{
УЗЛОВ К. И. ${ }^{1 *}$, д. m. н., проф.,

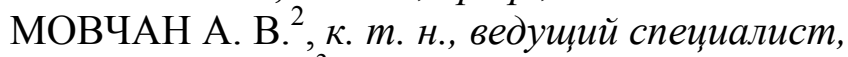 \\ ДЗЮБИНА А. В. ${ }^{3}$, аспирант, \\ БЕЛАЯ Е. В. ${ }^{4}$, магистр
}

${ }^{1 *}$ Кафедра материаловедения им. Ю. Н. Тарана-Жовнира, Национальная металлургическая академия Украины, пр. Гагарина, 4, 49600, Днипро, Украина, тел. +38(097)950-14-08, e-mail: konst.uzlov@gmail.com, ORCID ID: 0000-0003-0744-9890

${ }^{2}$ Кафедра термической обработки металлов им. К. Ф. Стародубова, Национальная металлургическая академия Украины, пр. Гагарина, 4, 49600, Днипро, Украина, тел. +38(097)128-17-81, e-mail: alvl.movchan@gmail.com

${ }^{3}$ Кафедра материаловедения им. Ю. Н. Тарана-Жовнира, Национальная металлургическая академия Украины, пр. Гагарина, 4, 49600, Днипро, Украина, тел. +38(093)205-29-37, e-mail: alinadzubina@,gmail.com

${ }^{4}$ Кафедра материаловедения им. Ю. Н. Тарана-Жовнира, Национальная металлургическая академия Украины, пр. Гагарина, 4, 49600, Днипро, Украина, тел. +38(097)215-23-93, e-mail: geben.seele@gmail.com

Аннотация. Постановка проблемы. Украина в рейтинге ведущих поставщиков отливок из медных сплавов входит в первую десятку. В последние годы наблюдается активный подъем их производства. Это объясняется расширением требований на медные сплавы не только в электротехнической, но и в других областях промышленности, в частности в автомобильной отрасли при производстве электрокаров. Цель работы. Анализ закономерностей формирования структуры сплавов системы медь-алюминий-железо при изменении количества легирующих компонентов для разработки технологических рекомендаций получения стабильно высокого уровня механических свойств литейных бронз в промышленном производстве и в эксплуатации. Материал и методика. Материалом исследования была литейная бронза БрА9ЖЗЛ по требованиям ГОСТ 493. Микроструктуру исследовали на металлографических шлифах, приготовленных по стандартным методикам ASTM E3-11. Анализ осуществляли с помощью световой микроскопии на оборудовании «Neophot-2». Растровые электронномикроскопические исследования и рентгеноспектральный микроанализ проводили на оборудовании Superprobe-733. Результаты. С помощью сопоставительного анализа результатов исследования диаграмм фазовых равновесий бинарных и тройных систем компонентов $\mathrm{Cu}$, $\mathrm{Al}$, $\mathrm{Fe}$, методов рентгеноспектрального микроскопического и локального рентгеновского энергодисперсионного, решено противоречие относительно происхождения железосодержащей фазы в структуре бронзы БрА9Ж3Л. Установлено, что это фаза $\beta_{1}$, то есть $\mathrm{Fe}_{3} \mathrm{Al}$ с растворенными атомами меди (до 7,72 масс. \%) и цинка от 0,0 масс. \% до 0,68 масс. \%, в зависимости от содержания этого компонента в сплаве. Промышленными испытаниями эффективных технологических параметров метода центробежного литья показано, что его недостатки, связанные с расслоением материала отливки по ликватам, могут быть использованы в производстве как преимущество для рафинирования расплава при наличии в нем примесей эндогенного происхождения, в частности железосодержащей фазы $\mathrm{Fe}_{3} \mathrm{Al}$. Bbывды. Решен противоречивый вопрос о генезисе железосодержащей фазы в структуре бронзы БрА9Ж3Л. Установлено, что это фаза эндогенного происхождения $\beta_{1}$, то есть $\mathrm{Fe}_{3} \mathrm{Al}$. B производстве 
использованы эффективные технологические параметры метода центробежного литья для рафинирования расплава при наличии в нем примесей эндогенного происхождения.

Ключевые слова: медные сплавы; центробежное литье; литейная бронза; структурообразование; фазовый состав; легирование; рентгеноспектральный микроскопический анализ

\section{Problem Statement}

Ukraine in the ranking of castings from copper alloys leading suppliers is among the top ten [2]. In recent years there has been a rapid rise in their production [9]. This is due to expansion of demand for copper alloys not only in electrical engineering, but also in other areas of industry, in particular in automotive manufacturing of electric cars production [11].

Copper - aluminum - iron system alloys structure formation regularities analysis depending on amount of alloying components changing for technological recommendations development of a stable high level of mechanical properties of foundry bronzes obtaining in industrial production and operation have been the purpose of this work.

\section{Material and Methods}

Material of the study was casting bronze BrA9Zh3L according to GOST 493 requirements. Microstructure was investigated on metallographic specimens prepared according to standard methods as per ASTM E3-11. Analysis was performed using light microscopy on "Neophot-2" equipment. Scanning electron microscopy and X-ray spectral microanalysis were performed on Superprobe-733 equipment.

\section{Results and Discussion}

Among all tin-free foundry bronzes according to GOST 493 [3] BrA9Zh3L is one of the most popular commercial industrial electrotechnical products with high structural properties and with the best combination of durability and plasticity characteristics [1]. Tin-free foundry bronze chemical composition meets GOST 493 requirements [3]. Typical microstructure of aluminumiron BrA9Zh3L bronze is shown in Figure 1.

Figure 1 analysis demonstrates that aluminum bronze with iron alloying affects the lines and points of phase equilibrium positions with non-single-phase solid solution regular formation, but the structure characterized by presence of $\alpha-\mathrm{Cu}$ solid solution excess crystals and eutectoid component.

Microstructure in Figure 1, b evidences that iron effects not only on structure formation kinetics changing [14]. In addition to the main structural components in Figure 1, b branched small iron-containing phase crystals of endogenous origin are represented. According to [8] this phase is $\mathrm{Fe}_{3} \mathrm{Al}$. But, given the fact that there is a small iron amount in this alloy, authors [10] believe that this phase is $\mathrm{FeAl}_{3}$. Its nature and effective industrial method of separation determination was the main task of existing research.

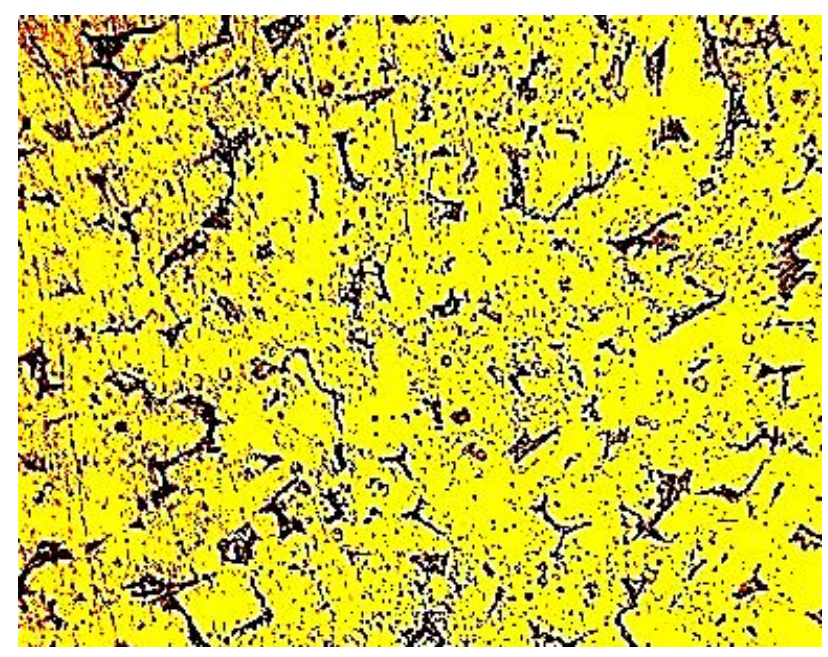

$a$

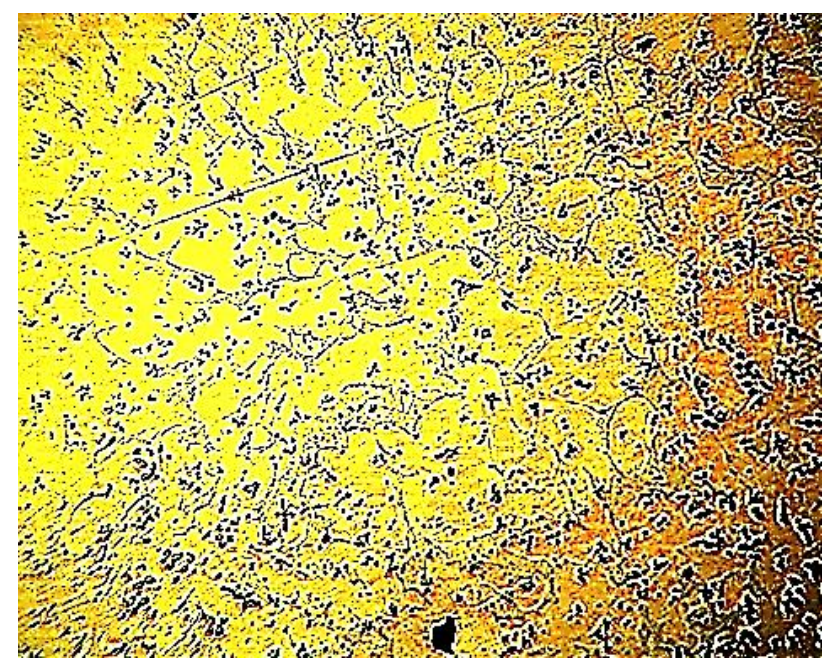

$b(б)$

Fig. 1. Casting bronze BrA9Zh3L typical microstructure (×100): $a$-after chemical etching, $b$-polished specimen / Рис. 1. Типова мікроструктура $(\times 100)$ ливарної бронзи БрА9ЖЗЛ: $a$ - після хімічного травлення, б-полірований зразок

Considered in Figure 1 BrA9Zh3L bronze microstructure provides mechanical properties achievements which are presented in Table 1 (GOST 493 [3]).

From the structural state presented in Figure $1 b$, it follows that this phase is placed evenly over the sample cross section, regardless of structural components distribution nature.

Aluminum bronze alloying with iron affects the phase equilibrium lines and points positions (in accordance with $\mathrm{Cu}-\mathrm{Al}-\mathrm{Fe}$ system triple phase diagram [12]).

Placement of this iron-contained phase evenly over sample intersection (Fig. $2 a, b$ ), regardless of structural 
components distribution nature, indicates its primary crystallization nature of origin and influence neutral character on phase transformations in system during foundry structural formation.

Table 1

Mechanical properties and applications of tin-less bronze / Механічні властивості та використання безолов'яної бронзи

\begin{tabular}{|c|c|c|c|c|c|}
\hline \multirow[t]{2}{*}{ Grade } & $\begin{array}{l}\text { Casting } \\
\text { Method }\end{array}$ & 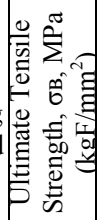 & $\begin{array}{c}\text { Elongation, } \\
\delta_{5}, \%\end{array}$ & $\begin{array}{c}\text { Brinell } \\
\text { Hardness, } \\
\mathrm{HB}, \mathrm{MPa} \\
\left(\mathrm{kgF} / \mathrm{mm}^{2}\right)\end{array}$ & \multirow[t]{2}{*}{ Application } \\
\hline & & \multicolumn{3}{|c|}{ Not less than } & \\
\hline \multirow{2}{*}{ BrA9Zh3L } & Chill & $\begin{array}{l}490 \\
(50)\end{array}$ & 12 & $980(100)$ & \multirow{2}{*}{$\begin{array}{c}\text { Reinforcement } \\
\text { and antifriction } \\
\text { parts }\end{array}$} \\
\hline & Sand & $\begin{array}{l}392 \\
(40)\end{array}$ & 10 & $980(100)$ & \\
\hline
\end{tabular}

Actual components number in "star-like" crystals of studied bronze iron-containing phase has been determined by X-ray energy-dispersion analysis method. Example of X-ray local energy-dispersion components microanalysis has been presented in Figure 3 . Quantitative data from five studies of X-ray spectral microanalysis measurements results are presented in Table 2. Table 2 data analysis shows that "star-like" crystals (Fig. 1-3) are iron-contained phase indeed with iron $81,20 \ldots 82,79$ wt. $\%$ to $9,86 \ldots 10,39$ wt. \% aluminum ratio. The established quantitative relation corresponds to $\mathrm{Fe}-\mathrm{Al}$ binary diagram region $[4 ; 7 ; 12]$ where phase $\beta_{1}$, i. e. $\mathrm{Fe}_{3} \mathrm{Al}$, is stable. In addition, according to energy dispersion analysis data, dissolved copper (up to 7,72 wt. \%) and zinc (from 0,0 wt. \% to 0,68 wt. $\%$, depending on its content in alloy respectively to GOST 493 [3] requirements) atoms present in this phase.

Table 2

\section{Quantitative data of bronze BrA9Zh3L local X-ray energy-dispersive analysis / Кількісні дані рентгенівського локального енергодисперсійного аналізу залізовмісної фази бронзи БрА9Ж3Л}

\begin{tabular}{|c|c|c|c|c|}
\hline \multirow{2}{*}{ Spectrum } & \multicolumn{4}{|c|}{ Component quantity, wt. \% } \\
\cline { 2 - 5 } & $\mathrm{Cu}$ & $\mathrm{Al}$ & $\mathrm{Fe}$ & $\mathrm{Zn}$ \\
\hline Spectrum 1 & 7,72 & 9,86 & 81,20 & 0,35 \\
\hline Spectrum 2 & 6,03 & 10,23 & 82,03 & 0,15 \\
\hline Spectrum 3 & 6,13 & 10,39 & 82,79 & 0,68 \\
\hline Spectrum 4 & 7,17 & 9,98 & 81,89 & 0,0 \\
\hline Spectrum 5 & 6,05 & 10,11 & 82,17 & 0,0 \\
\hline
\end{tabular}

Centrifugal method of industrial copper alloys casting [5; 6] has several advantages: resulting castings do not have shrinkage and gas shells, not clogged with slag, oxides and other nonmetallic inclusions. This technology is characterized by high productivity, lack of rods and work related to their manufacturing. Centrifugal casting is not limited by either the scale of production, type of alloy, or mold material. At the same time, authors $[5 ; 6]$ note among the shortcomings such as difficulty of manufacturing castings from alloys prone to liquation.

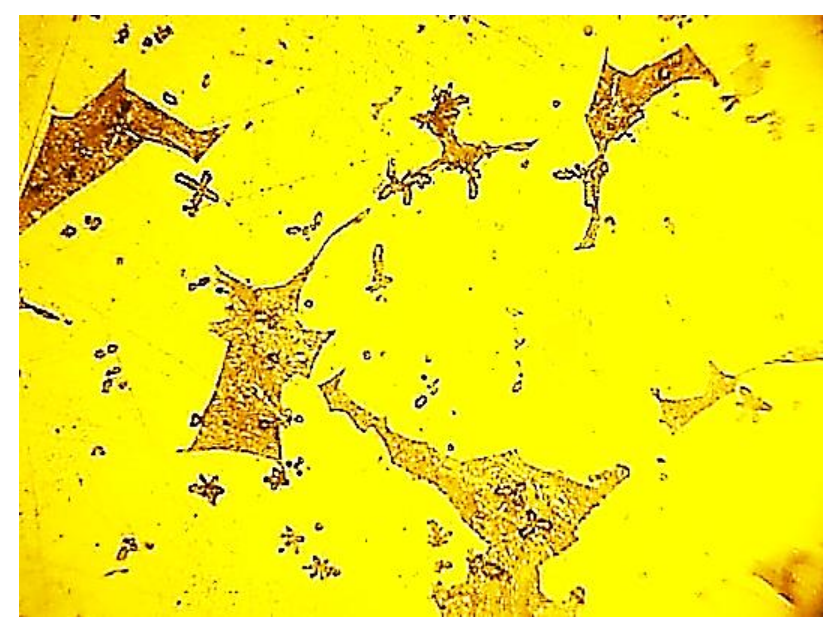

$a$

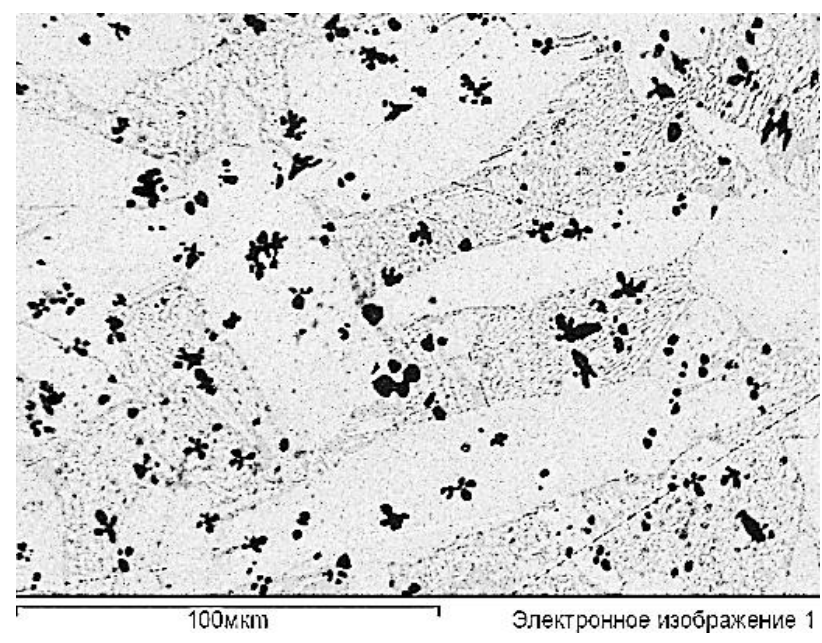

$b(6)$

Fig. 2. Endogenous impurities in casting bronze

BrA9Zh3L: a - metallographic presentation $(\times 500)$,

$b-S E M$ presentation in secondary electrons /

Pис. 2. Ендогенні включення у ливарній бронзі

БрА9Ж3Л: $а$-металографічне зображення (×500),

б - РЕМ зображення у вторинних електронах

But at the same time, disadvantages associated with casting material layering by liquates can be used in production as an advantage in the case of melt refining with endogenous origin impurities presence.

Indeed, using of centrifugal molding process effective technological parameters in castings bronze BrA9Zh3L production allow to conduct structural-free ironcontaining phase separation during cylindrical products in crystallizer solidification (Fig. 4). Such industrial procedure ensures the products from regular endogenous impurities refinement, which, in industrial exploitation, become generators of cracks and cast parts destruction. 


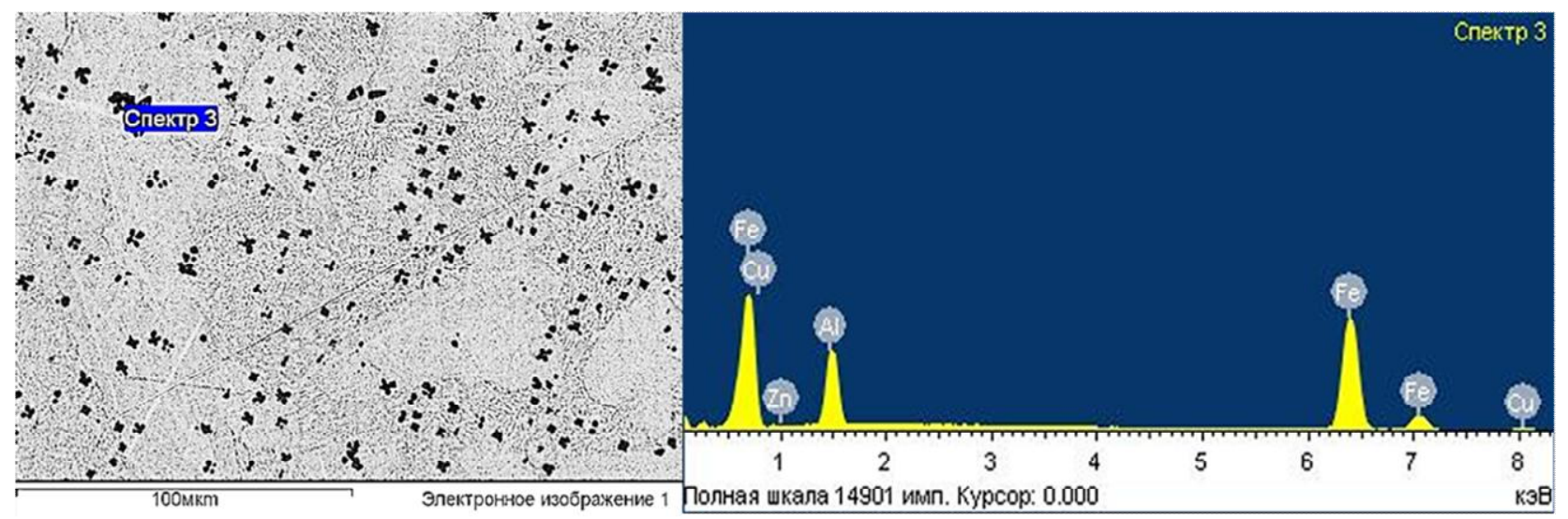

Fig. 3. Results of BrA9Zh3L quantitative X-ray energy-dispersive analysis / Рис. 3 Результати кількісного рентгенівського енергодисперсійного аналізу БрА9ЖЗЛ
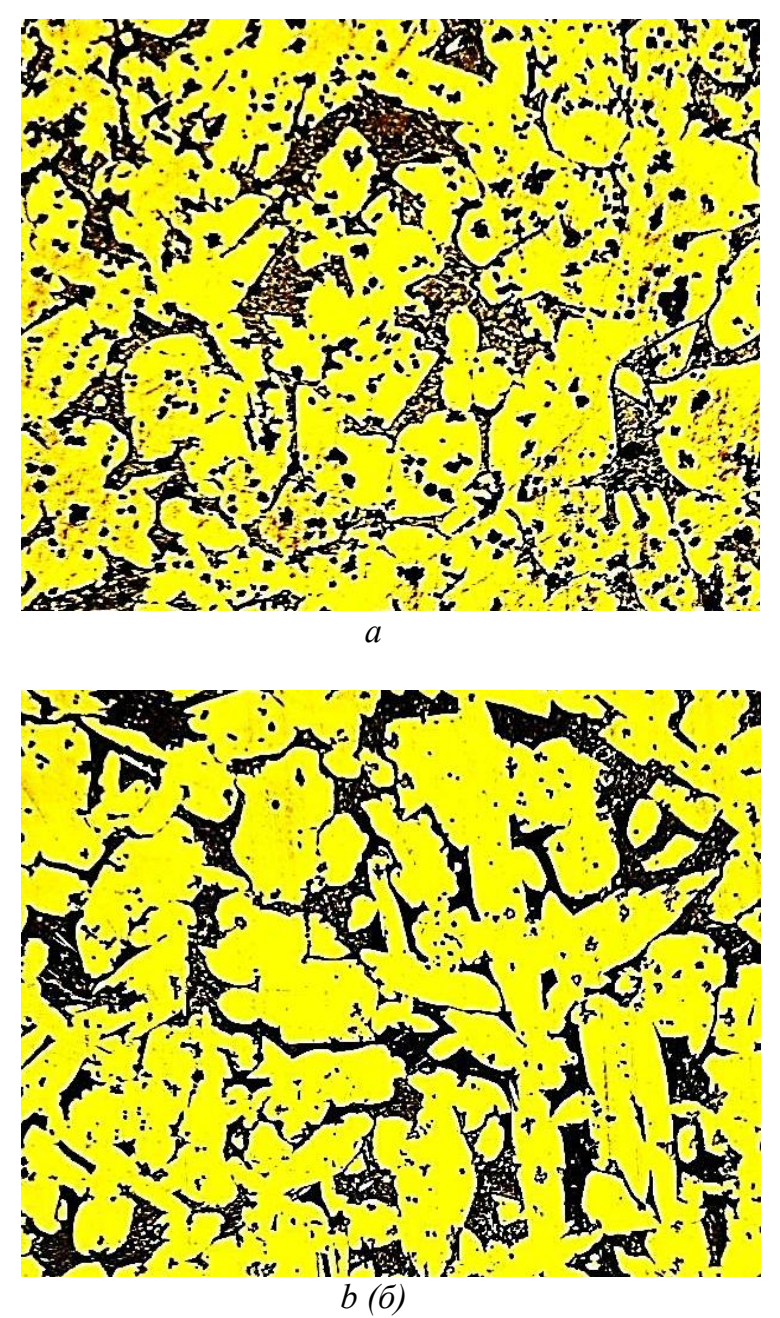

Fig. 4. Microstructures $(\times 200)$ of industrial bronze BrA9Zh3L: $a$ - chill mold casting, $b$ - centrifugal casting / Рис. 4. Мікроструктури $(\times 200)$ промислової бронзи БрА9ЖЗЛ: $а$-лиття в кокіль,

б - відиентрово литий виріб

Generally, implementation of rational doping new technological solutions and effective bronze BrA9Zh3L structural formation allows manufacture production to increase by $20 \%$ output quality casting, to reduce casting nonconformance by cracks in $2 \ldots 8$ times and to provide consistently high level of mechanical properties that result an improvement of products reliability and durability in industrial exploitation.

\section{Conclusions}

1. With the use of components $\mathrm{Cu}, \mathrm{Al}, \mathrm{Fe}$ binary and triple systems phase equilibrium diagrams studies, X-ray spectral microscopic and local X-ray energy dispersive methods results comparative analysis, origin of ironcontaining phase in bronze BrA9Zh3L structure has been discovered. It has been found that it is $\beta_{1}$ phase, i.e. $\mathrm{Fe}_{3} \mathrm{Al}$, with dissolved copper (up to 7,72 wt. \%) atoms and zinc from 0,0 wt. $\%$ to 0,68 wt. $\%$, depending on this component content in alloy.

2. Industrial tests of centrifugal casting method effective technological parameters have found that its disadvantages associated with casting material layering by liquates can be used in production as an advantage in case of melt refining from endogenous origin impurities presence, in particular iron-containing $\mathrm{Fe}_{3} \mathrm{Al}$ phase. 


\section{REFERENCES}

1. Boguslaev V.O., Repyakh S.I., Mogilatenko V.G. and oth. Livarni vlastivosti metaliv i splaviv dlya pretsiziynogo litva [Casting Properties of Metals and Alloys for Precision Casting]. Zaporizhzhia : AT "MOTOR SICH", 2016, 474 p. (in Ukrainian).

2. Gnatush V. Mirovoy ryinok litya 2012-2014: Itogi i prognozyi [World market of castings 2012-2014: Results and prognosis]. Agentstvo Lityo++Publ. Retrieved from: http://on-v.com.ua/novosti/biznes/mirovoj-rynok-litya-2012-2014-itogi-i-prognozy/ (in Russian).

3. GOST 493-79 (1979). Bronzy bezolovyannyie liteynyie. Marki [Tin-free foundry bronzes. Grades] (in Russian).

4. Dvoynyie i mnogokomponentnyie sistemyi na osnove medi [Binary and multicomponent copper based systems]. Edited by S.V. Shuhardina. Moscow : Nauka Publ., 1979, 249 p. (in Russian).

5. Kurdyumov A.V., Pikunov M.V., Chursin V.M. and Bibikov E.L. Proizvodstvo otlivok iz splavov tsvetnyih metallov [Casting Production from Nonferrous Metals]. Moscow : Metallurgiya Publ., 1986, 416 p. (in Russian).

6. Leybenzon V.O., Pilyushenko V.L., Kondratenko V.M. and oth. Tverdnennya metaliv i metalevih kompozitsiy [Solidification of Metals and Metallic Composites]. Kyiv : Naukova dumka Publ., 2009, 446 p. (in Ukrainian).

7. Lyakishev N.P. Diagrammyi sostoyaniya dvoynyih metallicheskih system : Spravochnik v 3-h tomah [Diagrams of double metallic systems state : Handbook in 3 Volumes]. Moscow : Mashinostroenie Publ., 1996-2000. (in Russian).

8. Maltsev M.V. Metallografiya promyishlennyih tsvetnyih metallov i splavov [Metallography of industrial non-ferrous metals and alloys]. Moscow : Metallurgiya Publ., 1970, 364 p. (in Russian).

9. Savenkov Yu.D., Dubodelov V.I., Shpakovskiy V.A., Kozhanov V.A. and Shtepan E.V. Rafinirovannaya med Ukrainyi [Refined Ukrainian Copper]. Donetsk : Izd-vo DonNTU, 2008, 176 p. (in Russian).

10. Smiryagin A.P., Smiryagina N.A. and Belova A.V. Promyishlennyie tsvetnyie metallyi i splavyi [Industrial non-ferrous metals and alloys]. Moscow : Metallurgiya Publ., 1974, 364 p. (in Russian).

11. Elektromobili protiv avto s DVS - itogi 2016 i perspektivyi 2017 [Electrical Cars against Auto with ICE - Results of 2016 and 2017 Perspectives]. EkoTehnika [EcoTechnic]. Retrieved from: https:// ecotechnica.com.ua/stati/1921-elektromobili-protiv-avto-sdvs-itogi-2016-i-perspektivy-2017.html (in Russian).

12. ASM Metals Handbook. Volume 03: Alloy Phase Diagrams (2016) / ASM International. Retrieved from: https://www.asminternational.org/documents/10192/1849770/05442G TOC.pdf/ecbf0e0e-cbe5-4d00-a82e-edc48bc156a4.

13. ASTM E3 - 11 (2017) Standard Guide for Preparation of Metallographic Specimens. Retrieved from: https://www.astm.org/Standards/E3.htm.

14. Uzlov K., Repiakh S., Mazorchuk V., Dziubina A. (2018). Phase Composition, Structure and Mechanical Properties of Industrial Bronze BrA9Zh3L Additionally Doped with Zinc. Scientific development and achievements: Monograph [Text]. LP22772, 20-22 Wenlock Road, London, N1 7GU, Vol. 5, Pp. 349-364. Retrieved from: https://www.google.com/search?q =Uzlov+K.\%2C + Repiakh + S. \% 2C + Mazorchuk + V.\%2C + Dziubina + A. $+(2018) .+$ Phase + Composition $\% 2 C+$ Structure + and + Mechanical + Properties + of + Industrial+Bronze+BrA9Zh3L+Additionally+Doped+with+Zinc. + Scientific + development + and + achievements\%3A+Monograph\&o $\mathrm{q}=$ Uzlov $+\mathrm{K} . \% 2 \mathrm{C}+$ Repiakh $+\mathrm{S} . \% 2 \mathrm{C}+$ Mazorchuk $+\mathrm{V} . \% 2 \mathrm{C}+$ Dziubina $+\mathrm{A} .+(2018) .+$ Phase + Composition $\% 2 \mathrm{C}+$ Structure + and $+\mathrm{Mechani}$ cal+Properties + of + Industrial+Bronze+BrA9Zh3L+Additionally+Doped+with+Zinc. + Scientific + development + and + achievements $\% 3$

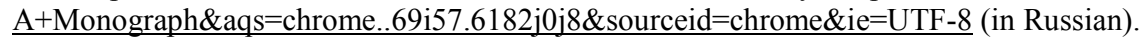

\section{СПИСОК ВИКОРИСТАНИХ ДЖЕРЕЛ}

1. Ливарні властивості металів і сплавів для прецизійного литва / [В. О. Богуслаєв, С. І. Реп'ях, В. Г. Могилатенко [та ін.]. - Запоріжжя : АТ «МОТОР СІЧ», 2016. - 474 с. - Режим доступу : http:// library.lp.edu.ua/ opac/page lib.php? docid= $\underline{498963 \& \text { mode }=\text { DocBibRecord }}$

2. Гнатуш В. Мировой рынок литья 2012-2014: итоги и прогнозы / В. Гнатуш. - Агентство Литье++. - Режим доступу : http://on-v.com.ua/novosti/biznes/mirovoj-rynok-litya-2012-2014-itogi-i-prognozy/

3. ГОСТ 493-79. Бронзы безоловянные литейные. Марки. - Режим доступу : http://www. galakmet.ru/directory/GOST/49379.pdf

4. Двойные и многокомпонентные системы на основе меди / Под ред. С. В. Шухардина. - Москва : Наука, 1979. - 249 с. - Режим доступу : https://markmet.ru/kniga-po-metallurgii/dvoinye-i-mnogokomponentnye-sistemy-na-osnove-medi

5. Производство отливок из сплавов цветных металлов / [А. В. Курдюмов, М. В. Пикунов, В. М. Чурсин, Е. Л. Бибиков]. - Москва : Металлургия, 1986. - 416 с. - Режим доступу : https://www. chipmaker.ru/files/file/13627/

6. Тверднення металів і металевих композицій / [В. О. Лейбензон, В. Л. Пілюшенко, В. М. Кондратенко [та ін.]]. - Київ : Наукова думка, 2009. - 446 с. - Режим доступу : http://www.irbis-nbuv.gov.ua/cgi-bin/irbis64r 81/cgiirbis 64.exe? $\mathrm{Z} 21 \mathrm{ID}=\& \mathrm{I} 21 \mathrm{DBN}=\mathrm{REF} \& \mathrm{P} 21 \mathrm{DBN}=\mathrm{REF} \& \mathrm{R} 21 \mathrm{DBN}=1 \& \mathrm{R} 21 \mathrm{DBN}=2 \& \mathrm{~S} 21 \mathrm{STN}=1 \& \mathrm{~S} 21 \mathrm{REF}=10 \& \mathrm{~S} 21 \mathrm{FMT}=$ fullwebr $\& \mathrm{C} 21 \mathrm{COM}=\mathrm{S}$ $\underline{ } \& 21 \mathrm{CNR}=20 \& \mathrm{~S} 21 \mathrm{P} 01=0 \& \mathrm{~S} 21 \mathrm{P} 02=0 \& \mathrm{~S} 21 \mathrm{P} 03=\mathrm{A}=\& \mathrm{~S} 21 \mathrm{COLORTERMS}=1 \& \mathrm{~S} 21 \mathrm{STR}=\% \mathrm{D} 0 \% 9 \mathrm{~B} \% \mathrm{D} 0 \% \mathrm{~B} 5 \% \mathrm{D} 0 \% \mathrm{~B} 9 \% \mathrm{D} 0 \% \mathrm{~B} 1 \%$ $\mathrm{D} 0 \% \mathrm{~B} 5 \% \mathrm{D} 0 \% \mathrm{BD} \% \mathrm{D} 0 \% \mathrm{~B} 7 \% \mathrm{D} 0 \% \mathrm{BE} \% \mathrm{D} 0 \% \mathrm{BD} \% 20 \% \mathrm{D} 0 \% 92 \$$

7. Диаграммы состояния двойных металлических систем : справочник в 3-х томах / Н. П. Лякишев. - Москва : Машиностроение, 1996. - Режим доступу : https://www.twirpx.com/file/337860/

8. Мальцев М. В. Металлография промышленных цветных металлов и сплавов / М. В. Мальцев - Москва : «Металлургия», 1970. - 364 с. - Режим доступу : https://www.studmed.ru/malcev-mv-metallografiya-promyshlennyh-cvetnyhmetallov-i-splavov d80d46186cb.html

9. Рафинированная медь Украины / [Ю. Д. Савенков, В. И. Дубоделов, В. А. Шпаковский, В. А. Кожанов, Е. В. Штепан]. - Донецк : Изд-во ДонНТУ, 2008. - 176 с. - Режим доступу : http:// webcache.googleusercontent.com/ search?q=cache:hqplCBrLT0J:https://steeltimes.ru/books/colormet/refiningcopper/ $\quad$ refiningcopper.php\&hl= ru\&gl=ua\&strip= $\underline{1 \& \text { vwsrc }=0}$ 
10. Промышленные цветные металлы и сплавы / [А. П. Смирягин, Н. А. Смирягина, А. В. Белова]. - Москва : Металлургия, 1974. - 488 с. - Режим доступу : https://www.chipmaker.ru/files/file/3927/

11. Электромобили против авто с ДВС - итоги 2016 и перспективы 2017 / ЭкоТехника. - Режим доступу : https://ecotechnica.com.ua/stati/1921-elektromobili-protiv-avto-s-dvs-itogi-2016-i-perspektivy-2017.html

12. ASM Metals Handbook. Volume 03: Alloy Phase Diagrams (2016) / ASM International. - Режим доступу : https://www.asminternational.org/documents/10192/1849770/05442G_TOC.pdf/ecbf0e0e-cbe5-4d00-a82e-edc48bc156a4

13. ASTM E3 - 11 (2017). Standard Guide for Preparation of Metallographic Specimens. - Режим доступу : https:// www.astm.org/Standards/E3.htm

14. Phase Composition, Structure and Mechanical Properties of Industrial Bronze BrA9Zh3L Additionally Doped with Zinc. Scientific development and achievements: Monograph [K. Uzlov, . Repiakh, V. Mazorchuk, A. Dziubina]. 2008, LP22772, 20-22 Wenlock Road, London, N1 7GU. - Vol. 5. - Pp. 349-364. - Режим доступу : https://www.google.com/search?q= Uzlov + K. $\% 2 \mathrm{C}+$ Repiakh + S. $\% 2 \mathrm{C}+$ Mazorchuk + V. $\% 2 \mathrm{C}+$ Dziubina + A. $+(2018) .+$ Phase + Composition $\% 2 \mathrm{C}+$ Structure + and + Mechanical + Properties + of + Industrial + Bronze + BrA9Zh3L + Additionally + Doped + with + Zinc.+ Scientific + development + and + achievements $\% 3 \mathrm{~A}+$ Monograph\&oq=Uzlov+K.\%2C+Repiakh+S.\%2C+Mazorchuk+V.\%2C+Dziubina+A.+(2018).+Phase+Composition\%2C+Structure + and + Mechanical+Properties + of + Industrial + Bronze + BrA9Zh3L + Additionally + Doped + with + Zinc.+ Scientific + development + and + ac hievements\%3A+Monograph\&aqs=chrome. $69 \mathrm{i} 57.6182 \mathrm{j} 0 \mathrm{j} 8 \&$ sourceid $=$ chrome $\& \mathrm{ie}=\mathrm{UTF}-8$

Стаття рекомендована до публікаиії д-ром техн. наук, проф. В. С. Вахрушевою (Украӥна), д-ром техн. наук, доч. Т. О. Дергач (Украӥна).

Стаття надійшла до редакції 21.03.2019

Прийнята до друку 26.03.2019 